\title{
Love Jihad and the Governance of Gender and Intimacy in Hindu Nationalist Statecraft
}

\author{
Kenneth Bo Nielsen ${ }^{1, *}$ and Alf Gunvald Nilsen ${ }^{2}$ \\ 1 Department of Social Anthropology, University of Oslo, 0317 Oslo, Norway \\ 2 Department of Sociology, University of Pretoria, Pretoria 0002, South Africa; Alf.Nilsen@up.ac.za \\ * Correspondence: k.b.nielsen@sai.uio.no
}

Citation: Nielsen, Kenneth Bo, and Alf Gunvald Nilsen. 2021. Love Jihad and the Governance of Gender and Intimacy in Hindu Nationalist Statecraft. Religions 12: 1068. https://doi.org/10.3390/rel12121068

Academic Editors: Iselin Frydenlund and Eviane Leidig

Received: 17 September 2021 Accepted: 13 November 2021 Published: 2 December 2021

Publisher's Note: MDPI stays neutral with regard to jurisdictional claims in published maps and institutional affiliations.

Copyright: (c) 2021 by the authors. Licensee MDPI, Basel, Switzerland. This article is an open access article distributed under the terms and conditions of the Creative Commons Attribution (CC BY) license (https:// creativecommons.org/licenses/by/ $4.0 /)$.

\begin{abstract}
What role does the Islamophobic theory of "love jihad" play in the politics of Hindu nationalist statecraft — the legal codification of Hindu nationalist ideology—in India today? In this article, we address this question through a critical analysis of how the idea of "love jihad" relate to both (a) a conservative politics of governing gender and intimacy in which women are constituted as subjects of protection and (b) an authoritarian populism grounded in a foundational opposition between true Indians and their anti-national enemies within. The article begins by exploring how "love jihad" has transformed from an idea that was used to legitimize extra-legal violence by Hindu nationalist vigilantes to the status of law, with a particular focus on the BJP-ruled state of Uttar Pradesh. We then situate the "love jihad" laws in relation to a regime of gender governance that constitutes women as subjects of protection-and specifically protection by state and nation - and discuss how this resonates with a pervasive patriarchal common sense in Indian society. Finally, we show how "love jihad" laws and the wider conservative politics of gender and intimacy within which it is embedded feeds into the authoritarian politics of the Modi regime, in which Muslims are consistently portrayed as enemies of the Indian nation, and reflect on what this entails for the country's secular political order.
\end{abstract}

Keywords: love jihad; Hindu nationalist statecraft; authoritarian populism; law; gender and intimacy

\section{Introduction}

"Cut my own throat if I'm lying, but I swear to you: around us right now, all around us, are Hindu women held captive by Muslim husbands". This is how Vijaykant Chauhan, a Hindu nationalist activist from the city of Saharanpur in Uttar Pradesh, explained his dedication to fighting against love jihad. He continued: "Islamic terrorists are using the sacred land of Hindustan, the wealth of Hindustan and Hindustan's daughters to breed children who are sent to madrasas, trained in Pakistan and turned into more terrorists who want to destroy India" (Sethi 2015). Chauhan was speaking to journalist Aman Sethi in early 2015, a little more than six months after the Bharatiya Janata Party (BJP) of Narendra Modi swept to national power for the first time after a monumental victory in the 2014 general election, and some two years before Yogi Adityanath would take power as BJP Chief Minister in Uttar Pradesh. His fierce dedication to a vigilantism that primarily targeted young people suspected of being involved in interfaith (Hindu-Muslim) relationships was, at this point in time, the primary manifestation of Hindu nationalist activism against the spectre of love jihad, and this activism, in turn, was very much an integral part of the more general rise of Hindutva vigilantism during the first term of Modi as Prime Minister (see Jaffrey 2021).

Fast forward to November 2020: having spent much of his first years in office playing up the issue, Chief Minister Adityanath finally announced at an election rally that his government was getting ready to act on love jihad "in a firm way" (Varadarajan 2020). He went on to say that his government would "bring an effective law-those who hide their name and identity and play with the honour of daughters and sisters, I am warning 
them in advance: if they don't stop, their funeral processions will be taken out" (ibid). This statement by Adityanath foreshadowed the introduction a few days later of an ordinance regulating and partly banning religious conversions in the state.

The introduction of the ordinance must be seen in the context of two other recent developments with which it worked in tandem. In 2019, the state law commission had produced a report recommending precisely such legislation. The cover of that report had, tellingly, featured a photo from hindujagruti.org, a website for an organization working for the establishment of a Hindu Rashtra, that is, a Hindu state. The contents of the report were arguably geared towards the same goal (Varadarajan 2020). Then, in October 2020-just a month before the election rally mentioned above- the Uttar Pradesh government launched its "Mission Shakti" with the stated aim of guaranteeing respect and safety to women in the state. ${ }^{1}$ In tweets commenting on the launch of "Mission Shakti", chief minister Adityanath wrote that women are "sacred as per the traditions of the Sanatan Dharm", i.e., Hinduism; and that there was "a need to make the new generation the carriers of this culture". He also warned that those who try to hurt the self-respect and dignity of women would not find any place in the "new Uttar Pradesh" (Financial Express Online 2020).

Then, in late November, the recommendations of the state law commission were enshrined in law through the introduction of the abovementioned ordinance which bears the full name The Prohibition of Unlawful Conversion of Religion Ordinance 2020. Unlike most earlier laws from other Indian states that similarly regulated religious conversions, which we review later, the new Uttar Pradesh ordinance did not invoke the trope of "freedom of religion" in its name, but was explicit about its prohibitive nature. In addition, while the law text did not address love jihad specifically, a government spokesperson who presented the ordinance to the media made the connection between the new legislation and the war against love jihad unambiguously clear: "Today, the Uttar Pradesh cabinet decided to introduce an ordinance against unlawful religious conversions. More than 100 cases of 'love jihad' have been reported in the last few months in Uttar Pradesh, so we are bringing an ordinance against these unlawful religious conversions", he said (Srivastava 2020).

Ismat Ara (2021) has described the love jihad ordinance as "a moment of glory for Hindutva foot soldiers" - the legislation, she correctly points out, is "the consequence of years of work by ground workers of Hindutva groups". However, the trajectory of the Islamophobic phantasm of love jihad from being a rallying cause for Hindutva vigilantism to being the cornerstone of state law is also part and parcel of another disconcerting political process in India today; namely, what we in previous work have referred to as Hindu nationalist statecraft-that is, the codification of Hindu nationalist ideology, and specifically the ideological tenet that India is and should be a Hindu nation, into law (Nielsen and Nilsen 2021; see also Jaffrelot and Verniers 2020). Hindu nationalist statecraft, as we elaborate below, has come to the fore in BJP governance since the re-election of Modi in 2019. It is an integral element in a hegemonic project, which has fused parliamentary and extra-parliamentary politics, and which has successfully widened the social foundations of the BJP — and the wider Hindu nationalist movement that it is a part of-to encompass subaltern social groups, such as the working poor, lower castes, and Dalits (see, e.g., Jaffrelot 2014, 2019a; Nilsen 2021).

In this article, we reflect on what the introduction of laws against love jihad tells us about the politics of Hindu nationalist statecraft. Towards this end, we simultaneously trace the journey of the trope of love jihad into law, while also working with love jihad as an analytical concept to explore the contemporary consolidation of Hindu nationalism in India (see also Frydenlund and Leidig Forthcoming, this issue). A caveat is necessary here: our argument is, of course, not that the regulation of gender relations and intimacies along religious lines is a uniquely Hindu nationalist concern (see e.g., Mody 2008). For example, Tanika Sarkar (2001, p. 17) has shown how a conservative and religiously demarcated gender ideology emerged as early as the late nineteenth century among a Bengali Hindu middle class that responded anxiously to perceived threats from lower classes and castes, as well as from Muslims, to "an earlier sense of impregnable securities written into the 
state structure". A cultural nationalism crystallized, centred on the assertion of custom and tradition, in which the chaste Hindu wife was "the condition of the possible Hindu nation" (ibid, p. 41). This has, of course, been an enduring ideological motif in Indian political and social reform movements, and not one that has been exclusive to the rightwing forces of Hindu nationalism (see e.g., Frøystad, this issue). What we are concerned with in this article, rather, is to decipher how the specific weaponization of the governance of gender relations and intimacy through anti-love jihad laws contributes to the rise of an "ethnic democracy" (Jaffrelot 2019b, 2021) in India, anchored in Hindu nationalism and a concurrent rejection of non-Hindu minorities. ${ }^{2}$

Our analysis does this in the following steps. First, we situate current anti-love jihad laws in relation to the politics and ideology of Hindu nationalism and Hindu nationalist statecraft. We focus on how the roots of this legislation can be traced to majoritarian demographic anxieties that were important in animating early Hindu nationalist ideology, and then trace the journey of this ideological construct into law in the state of Uttar Pradesh in the context of the rise to power of Modi in India. We then move on, in the second section, to present a close reading of the Prohibition of Unlawful Conversion of Religion Ordinance 2020 and the multiple ways in which the law complicates or criminalizes interfaith intimacies. In addition to suggesting that anti-love jihad laws shed light on potentially new spatial dynamics of Hindu nationalist statecraft, we illustrate how these laws work as a form of moral regulation. In the third and final section of the article, we discuss how the enforcement of anti-love jihad laws happens through synergies between the public authority of the state and the assertion of vigilante power, focusing in particular on what this tells us about the evolving nature of Hindu nationalism as a hegemonic project. Our conclusion summarizes our argument and reflects on the likely future trajectory of Hindu nationalist statecraft through legislation, particularly another new law just introduced in Uttar Pradesh aiming to curb Muslim population increase.

\section{Love Jihad in the Ideology and Politics of Hindu Nationalism}

The idea of love jihad refers to the alleged practice of Muslim men converting young Hindu girls to Islam through marriage. "The Love Jihad campaign", Priya Chacko (2020, p. 213) writes, "claims that Muslim men seduce, convert, marry, and have children with non-Muslim women to ensure that the Muslim minority in India becomes a majority". Significantly, in Hindu nationalist imaginaries, conversion to Islam is considered to be animated by a sinister conspiracy that threatens to undermine the cultural pre-eminence of Hinduism in India and, therefore, also national unity (Andersen and Damle 2019, chap. 10). ${ }^{3}$

As such, both activism and lawmaking in opposition to love jihad are directly related to the very core of the ideology and politics of Hindu nationalism. Hindu nationalism, as Christophe Jaffrelot (1996) has detailed in his landmark study, emerged as a movement in the early twentieth century, working against the grain of the intense differentiation of Hinduism as a religion to build India as a unitary Hindu nation (see also Noorani 2019; Bhatt 2001). As a specific form of ethnic nationalism, Jaffrelot (1996, p. 6) points out, Hindu nationalism defined a collective identity for itself by pursuing both a "defensive stigmatization" and a "strategic emulation" of Others that were viewed as external threats to the civilizational and cultural unity of the Hindu nation-more specifically, Christian missionaries, British colonial rulers, and, importantly, Muslims. In opposition to these Others, and in their quest to build an assertive and unified Hindu identity, the ideologues of the Rashtriya Swayamsevak Sangh (RSS) - the key organization in the Hindu nationalist "family of organisations" - drew sustenance from a mythical Vedic Golden Age that became "one of the cornerstones of Hindu nationalism" (ibid, p. 11).

There is a very real way, then, in which Hindu nationalism is grounded in a structure of feeling that is underpinned by "a Hindu sense of inferiority or vulnerability" (Jaffrelot 1996, p. 24) and, simultaneously, a "demographic anxiety" (Moodie 2008) that is distinctively anti-Muslim. At the core of this anxiety is the unfounded belief that Muslim population growth will dislodge Hindus from their position of dominance in India-a belief that 
has echoed through Hindu nationalist ideology since the early 1900s until the present (see Datta 1999; Rao 2011; Strohl 2019). Significantly, this structure of feeling, as well as the antidotes to it in Hindu nationalist politics, have always been profoundly gendered (see Anand 2011). As Sikata Banerjee (2005) has shown, Hindu nationalist ideology has persistently marshalled a notion of "masculine Hinduism", embodied in the Hindu solider and warrior-monk, against British colonial conceptions of the effeminate Hindu man. ${ }^{4}$ This, she argues, is not only an assertion against colonial emasculation, but also an assertion of masculine dominance over Hindu women, who in turn are defined in this ideological matrix by "female virtue and chastity" (ibid, p. 15). Himani Bannerji (2020, p. 459) has argued along similar lines that, at the level of everyday life, Hindu nationalist ideology and politics "is mediated and expressed through the ideals of the high-caste patriarchal family". According to Bannerji, the patriarchal Hindu family serves as a training ground for Hindutva masculinity, which is asserted as a counter to "male anxiety regarding virility and chastity" (ibid, p. 460). This, of course, entails dominance and control over the sexuality of Hindu women in the name of the Hindu nation: "Women's chastity and maternity are particularly important for their reproductive capacity as vessels for the nurturing of the Hindu race and its purity" (ibid, p. 460). This, however, does not mean that Hindu women are excluded from the sphere of militant Hindu activism, nor are they deprived of political agency. There exists a large number of "women's organizations" with Hindu nationalist orientations, including several in which female activists shoot rifles, learn karate, learn how to wield a lathi, participate in communal violence, and engage in other 'unfeminine' paramilitary activities, as they rise to the defence of a Hindu nation perceived to be under threat (Kovacs 2004; Sen 2007; Bedi 2016). However, such militancy is nonetheless both framed within and legitimized through the patriarchal logic of Hindu nationalist ideology that prescribes that Hindu women need protection against the menace of the Other-above all, of course, the Muslim Other (see Banerjee 2005).

As Charu Gupta (2009) has shown, India witnessed moral panics and political activism around purported Muslim conspiracies targeting Hindu women in the 1920s. More specifically, in the context of heightened communal tensions in Uttar Pradesh in the 1920s, Hindu publicists and Hindu revivalist organizations such as the Arya Samaj organized propaganda campaigns and demagogic appeals centred on the claim that Muslim men were abducting Hindu women and forcing them to convert to Islam. "The abducted and converted Hindu woman", Gupta writes, "was metamorphosed into a symbol of both sacredness and humiliation, and hence of the victimization of the whole Hindu community" (ibid, p. 13). This campaign hinged on an imaginary that was populated by valiant Hindu men defending their women and therefore their community; by Hindu women that were portrayed as innocent and passive victims; and by licentious Muslim men in pursuit of evil agendas (Gupta 2021). The sum effect, Gupta (2009, p. 13) argues, was that "the Hindu woman's body became a marker to sharpen communal boundaries in ways more aggressive than before" ${ }^{\prime \prime}$. A century later, the love jihad myth draws much of its political potency from "the anxiety of Islam overtaking the Hindu nation, through the body of the Hindu woman" (Tyagi and Sen 2019, p. 5). Indeed, as David Strohl (2019, p. 29) has argued, Hindu nationalist campaigns against love jihad "serve not only to demonize Muslims as improper citizens, but they also imbue an idealized patriarchal Hindu family with the civic duty to defend Hindu culture and the Hindu nation" (see also Gupta 2018). Plus, as he points out, these campaigns are grounded in persistent calls for Hindu men to protect and save young women (Strohl 2019, p. 30). This call reflects anxieties both about the threat of Muslim demography and about a perceived diminution of patriarchal authority (see also Chacko 2020, pp. 213-17).

However, activism, vigilantism, and law-making against love jihad now take place in an entirely new phase in the development of Hindu nationalist politics, as well as in an unprecedented and profoundly perilous conjuncture in the trajectory of the Indian polity. The defining feature of this phase of development is the rise of the BJP, under the leadership of Narendra Modi, as a hegemonic force in Indian politics. This rise has been 
signaled, above all, by two consecutive sweeping victories in the general elections of 2014 and 2019-the 2014 election saw the party win 31\% of votes and an absolute majority of 282 of 543 elected seats in parliament, while the 2019 elections saw the vote share of the party rise to $37.46 \%$ and 303 parliamentary seats. The rise of the BJP under Modi has been propelled by a hegemonic project of authoritarian populism, which has succeeded in consolidating a Hindu vote base across caste and class lines. This project was initially centred around a narrative that posited Modi as a vikas purush - a man of developmentwho would bring economic growth and good governance to the Indian people, upending the corrupt and dynastic rule of Congress. Hindu nationalist ideology was not absent from the political messaging of the BJP, but it was toned down in favour of a rhetoric that promised material progress and social mobility through market-based growth. This began to change after the first government under Modi had been installed: majoritarian cultural politics began to make itself present, and was manifest both in hate speech and vigilante attacks on vulnerable majorities-particularly Muslims. Significantly, religious conversion and the policing of inter-faith relationships were important loci around which this cultural politics has crystallized (see Nilsen 2021). This was particularly evident in the massive and generally coercive drive, spearheaded by the VHP, to convert Muslims and Christians to Hinduism that commenced soon after Modi assumed office. Such conversions are, in Hindutva language, known as ghar wapsi, literally meaning "returning home" or "homecoming". Hindutva activists define them as "reconversions" rather than conversions-a method for bringing wayward erstwhile Hindus back into "the Hindu fold". The practice of ghar wapsi is based on the explicit assumption that is foundational to Hindutva ideology, namely that Hinduism is the natural religion of the inhabitants of India (sometimes even of the entire world), while Muslims are denaturalized Hindus who have been converted by the sword to Islam (van der Veer 2021) and have been alienated from their Hindu cultural roots. As a coercive strategy, ghar wapsi was increasingly deployed by Hindutva groups to shore up the numerical strength and political power of "the Hindu community" in the early years of the Modi government (Katju 2015).

In the campaigning for the 2019 general election, there was an even clearer shift in the messaging of the BJP. In short, the party discarded its message of growth and development in favour of unbridled and unapologetic Hindu nationalism. The authoritarian populism of Modi has, of course, always been based on drawing a line between true Indians and their anti-national enemies, while subjecting the latter to coercion in order, supposedly, to protect the former. However, the line between true Indians and their enemies is now more explicitly drawn than ever in accordance with the tenets of Hindu nationalism. In other words, it is a line that is defined by religious majoritarianism, where the Muslim figures as the ominous Other that authoritarian populism depends on in order to frame a unitary conception of the nation and national culture. As noted above, this religiously defined dividing line is currently being codified into law, in a process of Hindu nationalist statecraft that allows religious majoritarianism to dictate law-making and override the precepts of secular constitutional morality, as well as the general democratic principle of protecting minority rights (Nielsen and Nilsen 2021). ${ }^{6}$

This process began with the abrogation of Kashmiri statehood in August 2019, relegating what was then the only Muslim-majority state in India to a union territory, and clearing the ground for advancing radical demographic changes (see Malji and Raza, this issue; Nilsen 2019a; Jaffrelot 2021, pp. 360-71). The symbolic politics of this legislative move is clear: the Hindu nation is to be built by purging Indian territory of the Muslim enemy within. The processes continued with the subsequent November 2019 Supreme Court verdict that awarded Hindus the right to the grounds where the Ayodhya mosque stood until it was demolished by Hindu nationalist activists in 1992. This lent credence to a weaponized mythology, which claims that this land is the birthplace of Lord Ram, and, therefore, rightfully belongs to the Hindu majority of India (Nilsen 2019b; see also Jaffrelot 2021, pp. 428-44). The Ayodhya judgment, in turn, was followed in early December 2019 by the passing into law of the Citizenship Amendment Act (CAA). Working in tandem 
with a national population register and a National Registry of Citizens (NRC), the CAA is likely to create a hierarchy of citizenship graded along religious lines, in which Indian Muslims end up as second-class citizens (Nilsen 2020; see also Jaffrelot 2021, pp. 377-84).

With the onset of Hindu nationalist statecraft, then, it is quite evident that the Modi regime has "radically changed gears and used the legislative and executive route to transform India into a de jure ethnic democracy" (Jaffrelot and Verniers 2020, p. 143). The love jihad laws that have been passed in Uttar Pradesh mark the most recent phase in this process. More specifically, it simultaneously marks a deepening and a transformation of the logic of Hindu nationalist statecraft. As we elaborate below, while the legal innovations discussed above can be said to target the macro-dimensions of state-making, the new legislation on love jihad shifts the scale to operate at the micro-scale of everyday gender relations and intimacies. Before we move on to consider the law itself in detail, however, we trace the trajectory of love jihad from a tenet of Hindu nationalist ideology and activism to legislation.

\section{The Emergence and Consolidation of "Love Jihad"}

While it draws on longstanding tropes in Hindu nationalist ideology, love jihad is a relatively new figment of the Hindutva imagination. It emerged in the late 2000s in order to stoke fears "over an unsubstantiated claim that hordes of Hindu women are converting to Islam and being duped into marriage to Muslim men by feigned declarations of love" (Kapur 2019, p. 362). As Kathinka Frøystad shows in her article in this special issue, its origins tend to be traced to the southern state of Karnataka, where Hindu nationalist activists led by Pramod Muthalik began using the term in 2005.

However, it was in Uttar Pradesh-recently described as a "majoritarian frontier" (Chatterji 2019, p. 418) —-that love jihad truly came to the fore as a prominent mobilizing issue in Hindu nationalist activism. As Pai and Kumar (2018) have argued, with the ascension of a new national leadership within the BJP-more specifically, Narendra Modi and current Home Minister Amit Shah-new strategies for drawing boundaries between Hindus and Muslims have emerged. Pai and Kumar refer to this strategy as "everyday communalism" and argue that it departs from earlier strategies of orchestrating spectacular large-scale violence and riots-such as what was witnessed in Ayodhya in 1992 and in Gujarat in 2002-as means of communal polarization. Instead, everyday communalism, as it has been fostered in Uttar Pradesh since the middle of the 2000s, uses small-scale communal incidents to foster constant and institutionalized tension and antagonism between Hindus and Muslims. The execution of this strategy has relied crucially upon the extra-parliamentary organizational network of the RSS,7 and not least on the current state Chief Minister Yogi Adityanath, who has played a vital role in this project. The career of Adityanath has crisscrossed extra-parliamentary and parliamentary domains since the late 1990s: as mahant (head-priest) of the Goraknath temple in eastern Uttar Pradesh, he has represented a non-Brahminical tradition of Hinduism and has expanded its philanthropic activities to the point where the temple functions as a kind of parallel government that enjoys substantial support among subaltern groups; he has also been a Member of Parliament since 1998, representing the BJP from the constituency of Gorakhpur (Pai and Kumar 2018, pp. 116-25; see also Jaffrelot 2014; Jha 2017). However, the most important vehicle for his political rise has been the Hindu Yuva Vahini (HYV), which he founded in 2002 in large part as a response to the backlash against the anti-Muslim pogroms that took place in Gujarat earlier the same year. With branches across all 72 districts of Uttar Pradesh, the HYV was founded with the explicit purpose of combating cow slaughter, religious conversion, and crimes against Hindu women, who Adityanath has described in his writings as in need of protection, not independence (Chatterji 2019, p. 409). Love jihad has been a particularly important rallying point for the organization and its activists (Pai and Kumar 2018, pp. 125-26).

The power base of Adityanath and the capacity of the HYV to mobilize communal agitation around relatively mundane day-to-day issues made him an invaluable asset to 
the BJP as the party sought to rebuild itself in electoral politics both in Uttar Pradesh and at the national level (Pai and Kumar 2018, pp. 151-60). In the lead-up to the 2014 general election, the party worked closely with Adityanath and the HYV to "deepen social divides between the majority and minority community" (ibid, p. 278). This paid off: the BJP won 71 out of 80 parliamentary seats in Uttar Pradesh, up from a mere 10 seats in the 2009 general election. Since then, the notion of "love jihad" has started circulating even more widely in the Indian public sphere (Jaffrelot 2019b), not least in Uttar Pradesh, where the HYV and others have intensified propaganda and vigilantism around the issue (Pai and Kumar 2018, pp. 278-79). This has continued to yield rich dividends for the BJP, as the party won $39.7 \%$ of the votes and 315 out of a total of 403 seats in the 2017 state elections in Uttar Pradesh. Yogi Adityanath was appointed as Chief Minister and has used this position to further his extreme Hindu nationalist politics (ibid, pp. 290-306). One of the results of this is the passage of the love jihad laws in late 2020, to which we now turn.

\section{Legislating against Love Jihad}

The Uttar Pradesh ordinance on religious conversions is one among several statelevel laws in India that regulate religious conversions. The RSS as well as the current home minister of India Amit Shah have repeatedly called for national legislation banning religious conversions in the entire country, but no such national law currently exists. The reason lies in the federal structure of India, under which religion and religious freedom are matters that lie exclusively under the constitutional domain of the states, as specified in Schedule 7 of the Indian Constitution.

At the subnational level, that is, at the level of the states, we find that several states have laws in place regulating, and often criminalizing, religious conversions. This generally occurs in the name of religious freedom - a term often used in the name of such acts-and ostensibly to provide legal "protection" to citizens against illicit conversions by means fair or foul. Yet, in practice, as we illustrate below, to the extent that these laws enshrine civil liberties and freedoms, they largely emphasize the freedom of citizens to remain within (or return to) the Hindu fold, where, according to the Hindu Right, all people residing in India properly belong. In this regard, the Uttar Pradesh ordinance is, as we mentioned earlier, somewhat exceptional insofar as its name explicitly signals an intention to prevent conversions rather than protect the freedom of religion.

A report by the Global Research Center at the US Law Library of Congress from 2018 lists 10 Indian states where such laws exist (Ahmad 2018). The oldest of these laws dates back to 1967 and was introduced in Orissa. Madhya Pradesh then introduced similar legislation the following year, and a few additional states followed later. The first decade of this millennium then witnessed enhanced legislative attention to the issue of conversions, with BJP-strongholds such as Madhya Pradesh and Chhattisgarh going the furthest to make existing state anti-conversion laws more stringent, or to introduce new laws to the same effect. Significantly, however, the only one of the 10 state laws examined in the report of the Law Library of Congress that specifically contains a provision on marriage and religious conversion is also the most recent to be discussed in the report, namely that which came into effect in Uttarakhand in 2017. This indicates that whereas religious conversions have been an enduring concern for Hindu nationalists, their explicit connection with marriage and sexuality in law is of a very recent date. This arguably indexes the enhanced traction of the love jihad discourse from the second decade of this millennium onwards. ${ }^{8}$

The Uttarakhand Freedom of Religion Act, 2018 (Government of Uttarakhand 2018), stipulates that "any marriage which was done for the sole purpose of conversion by the man of one religion with the woman of another religion either by converting himself before or after marriage or by converting the woman before or after marriage may be declared null and void" (emphasis added). Indeed, even if neither Islam nor love jihad are mentioned explicitly, the statement of objects and reasons that frames the act arguably comes very close to making this connection explicit. Here, the act speaks of "the presence of pseudo-social organizations with a hidden agenda to convert the vulnerable sections of other religions". 
It also mentions how some religions seek to increase their strength "by getting people from other religions converted to their own religion", and that "people do marry girls of other religion by misrepresentation of their own religion and after getting marriage to such girls, they get them converted to their own religion" or, conversely, that "people convert themselves to the other religion only for the purpose of marriage with the girl of that religion and after marriage they got that girl converted into their own religion" Clearly, it is the conversion of girls that is the crux of the matter.

While the Uttarakhand Freedom of Religion Act, 2018, was until recently unique in its emphasis on the connection between marriage and conversion, the report by the Law Library of Congress notes how similar the many different state anti-conversion laws are in both content and structure. This is arguably the outcome of considerable "legal mimicry" (Drumbl 2007) on the part of the states, who have sought and found legal inspiration in the existing laws of other states when drafting their own laws. For example, the anti-conversion provisions of Arunachal Pradesh from 1978 are penned along lines similar to those enacted in Orissa and Madhya Pradesh in the 1960s; anti-conversion laws in Tamil Nadu from the early 2000s similarly adhered to the general framework as laid down in the Orissa act from 1967; Chhattisgarh, which was established as a separate state in the year 2000 as a result of the partitioning of the southeastern districts of Madhya Pradesh, simply retained the anti-conversion law of Madhya Pradesh under a different name; the Himachal Pradesh Freedom of Religion Act, 2006, was similarly modelled on anti-conversion laws from other Indian states; prior to introducing anti-conversion legislation in Jharkhand in 2017, the state government reportedly studied the draft bills of other states such as Gujarat and Madhya Pradesh; Haryana, which is currently working on a new anti-conversion bill, is seeking inspiration in laws from Himachal Pradesh; the 2020 Uttar Pradesh ordinance, which we turn to soon, draws heavily on the Uttarakhand act from 2018; and so on (The Wire 2020). The result of such legal mimicry, whereby juridical ideas, formulations, and phrases travel from one context to another, is a patchwork of state-specific laws that are different in name but comparable in content, and where legal innovations in one state can quickly travel to other states. The fundamental goal in all of them is to limit the ability of communities and individuals to change their religion, often in the name of protecting the weaker sections of society: women, children, and backward castes. This is justified with particular reference to the use of forcible or fraudulent means, or of allurement or inducement, sometimes by way of marriage.

As such, anti-love jihad legislation also reveals some of the spatial complexities and flows of Hindu nationalist statecraft. Whereas the initial phases of Hindu nationalist statecraft—such as the abolition of Kashmiri statehood, the Ayodhya judgement, and the CAA/NRC initiative-emerged from above (from the central government and the apex court) and radiated outwards, anti-love jihad laws evidently circulate along lateral axes through legal mimicry and copying. This merging of Hindu nationalist statecraft from above, with what we may call lateral Hindu nationalist statecraft, arguably augurs a more densely woven hegemonic project on the part of the BJP and the Hindu nationalist movement.

\section{The Prohibition of Unlawful Conversion of Religion Ordinance 2020}

The Prohibition of Unlawful Conversion of Religion Ordinance 2020 (Government of Uttar Pradesh 2020) is a short text of just over nine pages. It consists of 14 main sections that make up the first 6 pages, while the remaining 3 pages contain 3 "schedules". In contrast to most other state laws regulating conversions, the Uttar Pradesh ordinance-in its Preamble and Sections 2 and 6-explicitly includes marriage within its scope, as it lists "marriage" as one among several possible ways of effecting an "unlawful conversion". Unlawful conversions are under this law, and regardless of the means through which they are effected, penalized with a jail term of 1 to 5 years with a minimum fine of INR 15,000, and 2 to 10 years of prison plus a fine of INR 25,000 or more for conversion of minors and women from the SC or ST community. 
That the Uttar Pradesh ordinance came into being through considerable legal mimicry is evident in, for example, Section 6, which is verbatim identical to Section 6 in the Uttarakhand Freedom of Religion Act, 2018, on which the Uttar Pradesh ordinance in general draws heavily. This section deals specifically with "marriages done for the sole purpose of unlawful conversion or vice versa by the man of one religion with the woman of another religion" and deems such marriages to be void. Whereas this is in fact the only section that deals explicitly with marriage, Section 8 that covers conversions in general also has significant implications for interfaith marriages. Section 8 requires that any person intending to convert-whether in connection with a marriage or not-must approach and inform the District Magistrate (DM) at least two months in advance, using the declaration form contained in Schedule I of the ordinance. The "religious convertor"-the person performing the act of conversion, to the extent that such an act is prescribed-is required to submit similar information about the exact date of the conversion ritual, etc., using the form in Schedule II. Upon receiving such information, the DM shall have an inquiry conducted by the police to ascertain the "real intention, purpose and cause" of the conversion. Any violation of this procedure, including the timely submission of written schedules, etc., will attract 6 months to 3 years of jail time and an INR 10,000 fine.

After conversion has taken place, the convert must send a declaration of conversion to the DM using the form contained in schedule III of the ordinance. A copy of this declaration must then be posted publicly on the notice board of the office of the DM until the convert has appeared in person in front of the DM to confirm the contents of the declaration. ${ }^{10}$ This requirement resembles that found in the Special Marriage Act of India, 1954, which specifies that couples wishing to conduct a civil marriage under this act must give written notice of 30 days to the Registrar, who is then obliged to post this notice publicly (Mody 2008, p. 115). We return to this family resemblance between the ordinance and the Special Marriage Act, 1954 , later.

The Uttar Pradesh ordinance deals with religious conversions in the abstract and does not mention any specific religion by name. Nor does it contain any references to love jihad, proselytization, missionary activities, or any other such activities that could be connected to a specific religion. However, the wider political context of Uttar Pradesh is defined by communal polarization and an aggressive love jihad rhetoric; the open threat of the chief minister to "those who hide their name and identity and play with the honour of daughters and sisters", as well as state-led campaigns to save and protect women in accordance with the teachings of the Sanatan Dharm, make it abundantly clear that the law is primarily targeted at Muslim men. So does the somewhat peculiar second paragraph of Clause 3 in the ordinance. This clause specifies that if a person reconverts to his/her "immediate previous religion", it shall not be deemed to be a conversion under this ordinance. Reconversions are in this way exempted from the cumbersome and timeconsuming work otherwise associated with a religious "conversion", and the clause thereby offers a speedy way of reversing a conversion. More specifically, given that the ordinance primarily targets conversions away from Hinduism, the clause first and foremost de facto enables a quick return to the Hindu fold. Moreover, given that Hindutva groups claim that all inhabitants of India were originally Hindus, Clause 3 also potentially provides a legal base for ghar wapsi insofar as it enables Hindutva groups to argue that any conversion to Hinduism should de jure be considered "a reconversion to a person's previous religion"; and that all conversions to Hinduism should therefore be exempted entirely from the strict provisions that otherwise apply to religious conversions. Strikingly, the clause also seems to imply that no reconversion is de jure criminalized, even if done through undue influence, allurement, or other such means as specified in the ordinance.

While the law text thus goes far in de facto criminalizing religious conversions in general, as well as in connection with marriage, there are several additional aspects beyond the letter of the law itself that stand out when they are considered in combination. First, the list of people deemed competent of lodging a first information report (FIR) ${ }^{11}$ in cases of unlawful conversion includes not only the aggrieved person herself, but also "any other 
person" related by blood, marriage, or adoption (Section 4). This includes, in other words, the father, mother, brothers, and sisters of the convert, as well as uncles, cousins, and so on, all of whom are empowered to lodge an FIR if a religious conversion is to take place in connection with a marriage. The list of people who are thereby empowered to object to or interfere in an interfaith marriage is consequently very long. Relatedly, the ordinance appears to contain a reverse onus clause that shifts the burden of proof onto the defendant-it specifies that the burden of proof as to whether a religious conversion was not effected through unlawful means be placed with the person who has "caused the conversion" (Section 12). Not only does this wording a priori assume that unlawful means must have been deployed in any act of conversion unless otherwise proven, but it apparently also means that it is the person carrying out or effecting the conversion, and not the convertee herself, who has to prove the consensual nature of the conversion.

Lastly, the mandatory use of "schedules" containing detailed personal information about the people involved in an act of conversion; their age, sex, occupation, and income; their kin; their residence; the date and time of conversion ceremonies; the name of the priest; the fact that these must be submitted to public authorities well in advance of any actual conversion, and that police inquiries are to be carried out in situ, combine to mean that detailed information about impending conversions will be at the very least in the semipublic domain. This is, of course, especially the case with Schedule III that is submitted after the act of conversion but before its legal recognition, and which must be posted on public noticeboards for several weeks. This means that detailed information about "planned conversions" becomes publicly available as a matter of state-sanctioned routine. In this context, a brief comparison with the Special Marriage Act, 1954, which we briefly discussed above and which similarly operates with a long "public notice period", is instructive. As Perveez Mody (2008) has shown, the clause in the 1954 act, specifying a long public notice period in connection with a civil marriage, is in key respects a carryover from an earlier colonial marriage act from 1872. More specifically, Mody argues that the mandatory long public notice period was the outcome of intense lobbying by conservative religious groups, who felt that "sufficient time should be allowed for families to travel to the relevant district and put forth their objections against the marriage of their children" (ibid, p. 68). The 1954 act retained and even expanded the long public notice period following a comparable logic, namely that "parents should be given ample opportunity to marshal their forces and raise whatever objections they might have against such marriages" (ibid, p. 68). In much the same way as the judicial process of public notice enshrined in the Special Marriage Act, 1954, in practice exposed the secrecy of the couples wishing to marry (ibid, p. 115), the judicial process of public notice in the Uttar Pradesh ordinance ensures not just exposure; it also offers valuable information on the basis of which to mount legal challenges to interfaith marriages, as well as-as we show in later sections-for extra-legal and vigilante action by Hindutva groups.

In addition to enabling the work of vigilante groups, the ordinance also criminalizes religious conversion to a greater extent than before; shifts the burden of proof; and crucially legitimizes and even mandates the intrusion of the state and third parties in the choice of who an individual wishes to marry (Vishwanath 2020). This, we suggest, constitutes a new dimension to Hindu nationalist statecraft. Previous milestones in Hindu nationalist statecraft arguably targeted what can be called the macro-dimensions of state-making, such as territory, demography, and citizenship. The abrogation of Kashmiri statehood, for example, was essentially an act of territorial engineering. Similarly, the CAA/NRC is concerned with citizenship and a majoritarian redefinition of national belonging. Together, the CAA and the NRC are likely to work as a demographic filtering device, banishing Muslims to second-class citizenship, if not from the remit of the nation as such (Nilsen 2020). While the new legislation against love jihad is, of course, also concerned with demographygrounded as it is in majoritarian demographic anxieties-it should also be taken as an indicator of how Hindu nationalist statecraft has come to operate at the micro-scale of everyday gender relations and intimacies. This is the domain of what Corrigan and 
Sayer (1985) have referred to as "moral regulation" in state formation. Corrigan and Sayer put forward this concept as part of their theorization of state formation as cultural revolution. Among the many "possible ways in which social life could be lived", they write, "state activities more or less forcibly 'encourage' some, whilst suppressing, marginalizing, eroding, undermining others" (ibid, p. 4). Moral regulation, in other words, renders specific ways of life natural in a way that is coextensive with a distinctive state form and the "moral ethos" that justifies that state form. A key aspect of moral regulation, in turn, is the building of the construct of the nation as a site of "primary social identification and loyalty" (ibid, p. 4) against a foil of alien others. The primary object of the analysis by Corrigan and Sayer, of course, was the western bourgeois state, but in the workings of anti-love jihad laws, it is possible to discern how moral regulation works to suppress, marginalize, erode, and undermine social intimacies that transcend the boundaries of religious communities in the Modi regime's "project of merging the nation-state with the Hindu people-nation" (Chatterjee 2020, p. 109).

\section{Law, State Power and Vigilante Activism in Hindu Nationalist Governance}

There is no doubt, then, that the anti-love jihad legislation has shaped governance in distinctive and significant ways. In fact, as soon as the ordinance had been introduced in late 2020, the Uttar Pradesh police began actively targeting interfaith couples. A few days after its enactment, the Lucknow police halted a wedding ceremony between a Hindu woman and a Muslim man, even though their families supported the union, in which neither party was going to convert (Kuchay 2020). The police team that stopped the wedding ostensibly intervened following a complaint by a local Hindu right-wing leader. In another case from the same month, a Muslim teenager was arrested under the law in Bijnor district, after the father of a 16-year-old Hindu girl claimed the boy had "induced his daughter to elope with him" with the "intention to marry and convert her" (Apoorvanand 2020). The unsuspecting couple was attacked by a group of men and taken to the local police station, where the boy was booked under the anti-conversion law and on charges of abduction. In addition to criminalizing Muslim men seeking to marry Hindu women, interfaith couples who married before the enactment of the legislation have also been targeted. For example, in one case, a Muslim man was arrested and sentenced to two weeks judicial custody for allegedly trying to pressure a Hindu woman into converting to Islam and eloping, following a case filed by her father. The alleged "pressure to convert", however, had been exercised back in 2019-long before the new law came into effect-and the "pressurized woman" had since then married a Hindu man. In another tragic case, a woman born into a Hindu family and her Muslim husband had gone to register their marriage in the town of Moradabad. Here, the man ended up in jail and the young woman in a state-run shelter home. Three months pregnant, she suffered a miscarriage.

In total, the first month after the ordinance was introduced saw 14 cases registered and 51 arrests made (Sahu 2021; see also Joshi 2020). All but one of these cases involved Hindu women allegedly pressured to convert to Islam. Tellingly, however, in 12 of these cases the complainant was not the woman herself, but her relatives. In at least two of them, Hindu right-wing activists are known to have intervened, for example, by holding protests at the police station. After 50 days, the number of cases had risen further. By then, 86 people had been named in first information reports (FIRs) related to the law. Of these, 79 were Muslims accused of "enticing a woman and forcing her to convert to Islam". Fifty-four people were arrested (Apoorvanand 2020). Notably, FIRs have not only targeted individual Muslim men but also their families. There have been cases of multiple family members of those arrested also being booked by the police (National Herald 2021). This includes 26 family members (including five women) of a Muslim man booked in Etah for allegedly forcing a 21-year-old Hindu woman to convert to Islam. In a similar case in Mau, an FIR was lodged against 16 members of a Muslim family, while in another case, 14 family members were booked in Sitapur. ${ }^{12}$ 
These examples-of which there are many more-show how the introduction of anti-love jihad legislation has enabled the state, via its apparatus of coercive power, to intervene in and-quite literally-police intimate relations in the private sphere according to the precepts of Hindu nationalism. As such, Uttar Pradesh and its anti-love jihad laws demonstrate just how real and tangible the impact of Hindu nationalist statecraft is in India today. However, if we really want to understand the dynamics of contemporary Hindu nationalist governance on the ground, we also need to consider the continued presence of vigilante groups in several of the examples above. As much as we argue that Hindu nationalist statecraft revolves around a process in which Hindutva ideology is transformed into law, this does not imply a neat shift from vigilantism to state administration as the key modality of enforcement of this ideology. Rather, in practice the anti-love jihad laws are brought to bear on everyday intimacies at the interface between the public authority of the state and the continued assertion of vigilante power. Indeed, as journalists Sharma and Khan (2021) have shown, the Uttar Pradesh ordinance has become an effective weapon in the armoury of Hindu nationalist vigilante groups. These groups learn about interfaith couples through dense networks of local informers, scattered across villages, towns, and cities. These informers can be found in schools and colleges, or working in buses, coffee shops, gyms, hotels, courts, and coaching centers. Marriage officials, Sharma and Khan note, also serve as important nodes in these networks. This modus operandi has been a staple in the repertoire of anti-love jihad activism for some time (see, for example, Goyal 2020; Bhat 2021), and vigilante gangs in Uttar Pradesh affiliated with the Bajrang Dal or other Hindu nationalist organizations have long resorted to conducting demonstrations outside police stations; "educating" the parents of girls to check the mobile phones of their daughters; and using Facebook and social media to check the identity and profile of suspected love jihadis, as ways of "combating" love jihad. However, with the new legislation at their disposal, Hindu nationalist activists can now more openly and assertively turn to police authorities "to inform them about couples on the run, demand surveillance of their mobile phones, and exchange updates on their whereabouts" (Sharma and Khan 2021, p. 7). With the introduction of the new legislation, these groups are able to align their activities more squarely with police intervention. "When a woman puts her foot outside her house without her father's permission, the Bajrang Dal comes in the picture", a Bajrang Dal leader in Uttar Pradesh told the reporter Ananya Bhardwaj (2020), explaining that "thanks to this law we can operate freely". With the new law in place, "the work that the VHP and the Bajrang Dal workers used to do on [their] own ... now has the full support of the police" (Sharma and Khan 2021, p. 8), as another Bajrang Dal leader told reporters Sharma and Khan. Obviously, Hindutva activists also use the new law to ensure that the police register cases against interfaith couples.

Hindutva activism, then, currently works in close tandem with the coercive apparatus of the state to enforce the majoritarian provisions of new legislation that are at the core of Hindu nationalist statecraft. In a recent article, Sana Jaffrey (2021) has correctly pointed out that vigilantism is indeed integral to authoritarian populist projects. Extra-legal violence, she argues, is used to police purported transgressions of the social order. By virtue of its disregard for institutional and legal constraints, vigilante violence complements the focus of authoritarian populist projects on the direct assertion of popular sovereignty. Using the anti-love jihad laws of India as an example, Jaffrey conceives of vigilantism as a kind of "violent lobbying" (ibid, p. 17) that right-wing populists engage in to "get the state to do their bidding" (ibid, p. 20). Such a reading, however, suggests a rather neat distinction between a private domain of vigilantism and a public domain of state power, with the former acting upon the latter in an attempt to advance its ideology. As the examples above indicate, such a distinction is untenable-not only in the context of love jihad and religious conversions, but also in other real-life manifestations of Hindutva ideology such as cow protectionism, where elected politicians and the police actively collaborate with armed vigilante gangs to target overwhelmingly Muslim cattle traders, transporters, tanneries, and butchers suspected of breaking cow protection laws (Ahuja 
2019; see also Jakobsen and Nielsen Forthcoming, Jakobsen and Nielsen Forthcoming). A more accurate reading, in our view, is that the confluence of vigilantism and police intervention in the enforcement of anti-love jihad laws testifies to how the hegemonic projects of dominant groups constantly crisscross the analytical divide between civil society and political society (in the Gramscian sense of those terms) ${ }^{13}$, when mobilizing coercive power. This is especially so in the case of Hindu nationalism as a hegemonic project, which, over a century-long period, has embedded itself as a political force in Indian society and steadily expanded its social foundations beyond its narrow elite origins. The Modi regime arguably represents a critical new phase in this process, in which the Hindu nationalist movement seems to have advanced to a point where it is able to assert a decisive hold on state power (see Jaffrelot 2021).

\section{Concluding Remarks}

In this article, we have developed an analysis of how the Islamophobic ideological construct of love jihad has recently been absorbed into what we refer to as Hindu nationalist statecraft, in the form of legislation governing gender relations and intimacies. Under the aegis of Yogi Adityanath and his outfit, the Hindu Yuva Vahini, love jihad emerged as a locus of Hindu nationalist activism from the early 2000s onwards, working to foster constant institutionalized tension and antagonism between Hindus and Muslims in the state. This allowed Adityanath to expand and consolidate his power base, and enabled him to rebuild the BJP as a political force to be reckoned with in Uttar Pradesh. The passage of the love jihad laws in late 2020 is, in turn, a direct result of the ascent of Adityanath to the position of Chief Minister in Uttar Pradesh three years prior, in 2017.

In deciphering the logic of legislation against love jihad, we stressed the considerable resemblance between the many state-level anti-conversion laws of India. These, we argue, are the result of widespread legal mimicry at play in shaping these laws, as different states copy, borrow, and find inspiration in each other's laws, past and present. This circulation of anti-love jihad laws along lateral axes arguably adds to the density of Hindu nationalist statecraft and is, to us, a promising avenue for future research. Crucial to our argument in this article, however, are the ways in which anti-love jihad laws add a new dimension to Hindu nationalist statecraft, by virtue of their targeting of the micro-scale of everyday gender relations and intimacies. Legislation against love jihad, we argued, is a form of moral regulation that aims to suppress, marginalize, erode, and undermine social intimacies that transcend the boundaries of religious communities-all of which underpins the making of a Hindu nation in India under Modi. This is arguably evident in the actual implementation of the new anti-love jihad laws in Uttar Pradesh, which has enabled the state, via its apparatus of coercive power, to intervene directly and police intimate relations in the private sphere in accordance with Hindu nationalist precepts-in close tandem with Hindutva activists and vigilantes. This effortless traversion of the analytical divide between civil and political society by Hindutva forces pushing their hegemonic project testifies to the very real and serious implications of the fact that the Hindu nationalist movement, with the BJP of Modi at the helm, currently asserts a decisive hold on state power.

The kind of Hindu nationalist statecraft that we have analyzed in this article-the codification into law of Hindu nationalist ideology and, specifically, the ideological tenet that India is and should be a Hindu nation - is an emerging and evolving phenomenon that only came to the fore in BJP governance with the re-election of Modi in 2019. While the future of Hindu nationalist statecraft is, therefore, uncertain and still in the making, it is clear that from the point of view of the BJP and allied organizations this form of statecraft promises rich dividends. First, it offers an effective de jure route through which to merge the nation-state with the Hindu people-nation, a merger that is central to Hindutva ideology. Second, this de jure route is pursued in a context in which "the idea that Hinduism is the national civilization of India has come to be common sense in a juridical and political sense" (van der Veer 2021, p. 51). This means that the popular and legal obstacles to Hindu 
nationalist statecraft are currently limited. Third, as Christian Lund (2020, p. 4) reminds us, the law works both as a solvent and a solidifier: legalization seeks to secure state power backing for a claim in order to solidify it as a right that forces competing claims to dissolve. The enshrinement of Hindu nationalist claims to the nation in state law not only solidifies it as a right to the nation, it also marginalizes competing claims, sometimes to the point of dissolving them. Lastly, locking in Hindu nationalist claims to the nation qua law promises to take this claim relatively safely through times of changing political fortunes for the BJP as a right.

It is, therefore, perhaps unsurprising that there are signs that more is to come in this regard. In early July 2021, for example, a draft of a new population control bill was published on the website of the Uttar Pradesh Law Commission (Business Standard 2020). The bill was preceded by several years of vocal agitation demanding such legislation by Hindutva groups in much of north and central India, alleging that Muslims were singularly responsible for driving up the population of India (Purohit 2019). The current draft bill proposes that couples who have more than two children will be barred from contesting local elections, applying for and being promoted in government jobs, and from receiving subsidies from the state. As critics have pointed out, the draft bill threatens to disempower women, as well as to disproportionately affect subaltern communities. Crucially, of course, it also feeds into and amplifies the same anti-Muslim demographic anxieties that animate the anti-love jihad laws and Hindu nationalist ideology more generally (Trivedi 2021). In addition, while the draft bill does not specify curbing the population growth of any particular religion or community, social media users have already used the bill as a basis to attack Muslims online, where false narratives about Muslims being responsible for the population explosion have spread aggressively. Should the bill, which is widely seen to be in contravention of the constitutional right to equality (see The Hindu 2021), be passed into law, it would constitute a radical further advance of Hindu nationalist statecraft in the domain of moral regulation.

Author Contributions: This article was developed and written in equal parts by both authors. All authors have read and agreed to the published version of the manuscript.

Funding: Alf Gunvald Nilsen would like to acknowledge the funding from the National Institute of Humanities and Social Sciences (South Africa) enabled his research for this article.

Conflicts of Interest: The authors declare no conflict of interest.

\section{Notes}

Mission Shakti approximately translates into "mission female power".

See Frydenlund (2017) for a discussion of similar developments in the context of Myanmar.

In practice, the share of Indians who switch religions is low and not a major factor in demographic change. For example, an extensive survey by the Pew Research Centre (2021) found that very few respondents had switched religions since childhood. Among surveyed adults who were raised as Hindus, $99 \%$ still identified as Hindu, while $97 \%$ of those raised as Muslims remained Muslims in adulthood. Moreover, those who do switch religions largely cancel each other out. For example, while $0.7 \%$ of the respondents were raised Hindu but do not currently identified as such, a slightly larger share (0.8\%) were raised outside of the religion but now consider themselves Hindu.

4 British colonialism did not construe all Indian men as effeminate, males belonging to the so-called "martial races," who were conceived as brave and well-built for fighting, being a case in point.

5 A similar logic is of course at play in the way that the bodies of women have been used as sites of gendered violence structured along religious lines in modern India. Urvashi Butalia (2000) and Veena Das (1996) have shown different aspects of this dynamic at play in relation to Partition, and Tanika Sarkar (2002) has argued that sexual violence perpetrated by Hindu men against Muslim women during the 2002 anti-Muslim pogrom in Gujarat constituted an attempt by the Hindu majority community to assert themselves against the perceived demographic advances of Muslims-even to the point of symbolically destroying future Muslim generations (see also Anand 2007).

6 India is arguably part of a wider trend in the Asian region in this regard (see, e.g., Hadiz 2018; Jayasuriya 2018; Jayasinghe 2020; Frydenlund 2017). 
7 As several commentators have noticed, the rise of Narendra Modi and Amit Shah in the BJP has also resulted in a realignment of relations between the BJP and the RSS, with the result that the RSS now exercises unprecedented levels of influence over the machinery of government (see Jaffrelot 2021).

8 Interestingly, the Jharkhand anti-conversion law that came into being the same year as that of Uttarakhand contains no specific provision on marriage. Again, the explicit connection between religious conversion, marriage, and sexuality in recent legislation in India seems to parallel developments in Myanmar (Frydenlund 2017).

9 Syntax in the original.

10 This must happen within 21 days of the sending of the declaration. Only after this process has been completed is the conversion confirmed, and the declaration presumably taken down-although this is not specified in the ordinance.

11 An FIR is a document prepared by the police when they first receive information about a cognizable offense. An FIR is typically required before the police will take up an actual investigation of a case.

12 While some Islamic organisations - such as the Dargah-e-Ala Hazrat, one of the most important shrines for the Barelvi sect of Sunni Muslims-have somewhat endorsed the ordinance by stressing that forcible conversions are against the tenets of Islam, and that there is no basis in Islam for the concept of love jihad, other organizations have protested against the hidden intentions of the ordinance. The Jamiat Ulama-i-Hind, for example, is party to petitions challenging the ordinance (and similar laws elsewhere in the country), not so much for their contents as for the fact that they have, as shown here, been used to harass Muslims across India.

13 Gramsci theorized the modern state in an expanded sense, as consisting of the relation between civil society-essentially, voluntary associations and institutions that orchestrate subaltern consent-and political society in the form of the formal apparatus of coercive state power (see Nilsen 2015 for a discussion).

\section{References}

Ahmad, Tariq. 2018. State Anti-Conversion Laws in India; Law Library of Congress. Available online: https://www.loc.gov/item/2018 298841/ (accessed on 12 April 2021).

Ahuja, Juhi. 2019. Protecting holy cows: Hindu vigilantism against Muslims in India. In Vigilantism against Migrants and Minorities. Edited by Tore Bjørgo and Miroslav Mareš. London: Routledge.

Anand, Dibyesh. 2007. Anxious Sexualities: Masculinity, Nationalism and Violence. British Journal of Politics and International Relations 9: 257-69. [CrossRef]

Anand, Dibyesh. 2011. Hindu Nationalism in India and the Politics of Fear. London: MacMillan Publishing.

Andersen, Walter, and Shridhar D. Damle. 2019. Messengers of Hindu Nationalism: How the RSS Reshaped India. London: Hurst and Co Publishers.

Apoorvanand. 2020. India's “Love Jihad" Laws: Another Attempt to Subjugate Muslims. Al Jazeera. Available online: https: / / www.aljazeera.com/opinions/2021/1/15/indias-love-jihad-laws-another-attempt-to-subjugate-muslims (accessed on 12 April 2021).

Ara, Ismat. 2021. Uttar Pradesh's “Love Jihad” Law Is a Moment of Glory for Hindutva Foot Soldiers. The Wire. Available online: https: / / thewire.in/communalism/uttar-pradeshs-love-jihad-law-is-a-moment-of-glory-for-hindutva-foot-soldiers (accessed on 15 April 2021).

Banerjee, Sikata. 2005. Make Me a Man! Masculinity, Hinduism, and Nationalism in India. Binghampton: SUNY University Press.

Bannerji, Himani. 2020. The Ideological Condition: Selected Essays on History, Race and Gender. Leiden: Brill.

Bedi, Tarini. 2016. The Dashing Ladies of Shiv Sena: Political Matronage in Urbanizing India. Binghampton: SUNY University Press.

Bhardwaj, Ananya. 2020. "We Step in when Our Women Step Out with Muslim Men"-How UP Law Empowers Hindu Bully Groups. The Print. Available online: https:/ / theprint.in/india/we-operate-freely-now-how-hindu-groups-are-driving-ups-crackdownon-love-jihad/574368/ (accessed on 15 April 2021).

Bhat, Prajwal. 2021. In Mangaluru, Hindutva Groups Wield a Web of Informers to Target Interfaith Friends. The Nezws Minute. Available online: https: / / www.thenewsminute.com/article/mangaluru-hindutva-groups-wield-web-informers-target-interfaith-friends151860 (accessed on 15 April 2021).

Bhatt, Chetan. 2001. Hindu Nationalism: Origins, Ideologies and Modern Myths. London: Routledge.

Business Standard. 2020. No Govt Job, Subsidy if over Two Children: UP Population Control Draft Bill. Business Standard. Available online: https: / www.business-standard.com/article/current-affairs/up-population-draft-bill-proposes-special-incentives-forparents-with-1-kid-121071000474_1.html (accessed on 18 April 2021).

Butalia, Urvashi. 2000. The Other Side of Silence: Voices from the Partition of India. Durham: Duke University Press.

Chatterjee, Partha. 2020. I Am the People: Reflections on Popular Sovereignty Today. New York: Columbia University Press.

Chatterji, Angana P. 2019. Remaking the Hindu/Nation: Terror and Impunity in Uttar Pradesh. In Majoritarian State: How Hindu Nationalism is Changing India. Edited by Angana P. Chatterji, Thomas Blom Hansen and Christophe Jaffrelot. Oxford: Oxford University Press.

Chacko, Priya. 2020. Gender and authoritarian populism: Empowerment, protection, and the politics of resentful aspiration in India. Critical Asian Studies 52: 204-25. [CrossRef]

Corrigan, Phil, and Derek Sayer. 1985. The Great Arch: English State Formation as Cultural Revolution. Oxford: Blackwell Publishers. 
Das, Vena. 1996. Critical Events: Anthropological Perspectives on Contemporary India. Delhi: Oxford University Press.

Datta, Pradip Kumar. 1999. Carving Blocs: Communal Ideology in Early Twentieth-Century Bengal. Delhi: Oxford University Press.

Drumbl, Mark A. 2007. Atrocity, Punishment, and International Law. Cambridge: Cambridge University Press.

Financial Express Online. 2020. Uttar Pradesh: Yogi Adityanath launches Mission Shakti for security of women in the state. Financial Express Online. Available online: https://www.financialexpress.com/india-news/uttar-pradesh-yogi-adityanath-launchesmission-shakti-for-security-of-women-in-the-state/2107931/ (accessed on 18 April 2021).

Frydenlund, Iselin. 2017. Religious Liberty for Whom? The Buddhist Politics of Religious Freedom during Myanmar's Transition to Democracy. Nordic Journal of Human Rights 35: 55-73. [CrossRef]

Frydenlund, Iselin, and Eviane Leidig. Forthcoming. Introduction: "Love Jihad": Sexuality, Reproduction and the Construction of the Predatory Muslim Male. Religions

Government of Uttar Pradesh. 2020. The Uttar Pradesh Prohibition of Unlawful Conversion of Religion Ordinance 2020. Lucknow: Government of Uttar Pradesh.

Government of Uttarakhand. 2018. The Uttarakhand Freedom of Religion Act. Dehradun: Government of Uttarakhand.

Goyal, Prateek. 2020. How Hindutva vigilantes are battling 'love jihad' in Madhya Pradesh. Newslaundry. Available online: https: / / www.newslaundry.com/2020/12/28/how-hindutva-vigilantes-are-battling-love-jihad-in-madhya-pradesh (accessed on 20 April 2021).

Gupta, Charu. 2009. Hindu Women, Muslim Men: Love Jihad and Conversions. Economic and Political Weekly 44 : 13-15.

Gupta, Charu. 2018. Allegories of "love jihad" and ghar wapsi: Interlocking the socio-religious with the political. In Rise of Saffron Power: Reflections on Indian Politics. Edited by Mujibur Rehman. London: Routledge.

Gupta, Charu. 2021. Love Taboos: Controlling Hindu-Muslim Romances. The India Forum. Available online: https://www. theindiaforum.in/article/love-laws-making-hindu-muslim-romances-illegitimate?utm_source=website\&utm_medium= organic\&utm_campaign=category\&utm_content=Law (accessed on 20 April 2021).

Hadiz, Vedi. 2018. Imagine All the People? Mobilising Islamic Populism for Right-Wing Politics in Indonesia. Journal of Contemporary Asia 28: 566-83. [CrossRef]

Jaffrelot, Christophe. 1996. The Hindu Nationalist Movement in India. New York: Columbia University Press.

Jaffrelot, Christophe. 2014. The other saffron. Indian Express. Available online: https://indianexpress.com/article/opinion/columns/ the-other-saffron/ (accessed on 20 April 2021).

Jaffrelot, Christophe. 2019a. Class and Caste in the 2019 Indian Election-Why Have So Many Poor Started Voting for Modi? Studies in Indian Politics 7: 149-60. [CrossRef]

Jaffrelot. 2019b. A De Facto Ethnic Democracy? Obliterating and Targeting the Other, Hindu Vigilantes, and the Ethno-State. In Majoritarian State: How Hindu Nationalism is Changing India. Edited by Angana P. Chatterji, Thomas Blom Hansen and Christophe Jaffrelot. Oxford: Oxford University Press, pp. 41-68.

Jaffrelot, Christophe. 2021. Modi's India: Hindu Nationalism and the Rise of Ethnic Democracy. Princeton: Princeton University Press.

Jaffrelot, Christophe, and Gilles Verniers. 2020. A New Party System or a New Political System? Contemporary South Asia 28: 141-54. [CrossRef]

Jaffrey, Sana. 2021. Right-Wing Populism and Vigilante Violence in Asia. Studies in Comparative International Development 56: $223-49$. [CrossRef]

Jakobsen, Jostein, and Kenneth Bo Nielsen. Forthcominga. Bovine Contradictions: The Politics of (De)-meatification and Hindutva Hegemony in Neoliberal India. In Changing Meat Cultures: Food Practices, Global Capitalism and the Consumption of Animals. Edited by Arve Hansen and Karen Lykke Syse. Lanham: Rowman and Littlefield.

Jakobsen, Jostein, and Kenneth Bo Nielsen. Forthcomingb. Bovine Meat, Authoritarian Populism and State Contradictions in Modi's India. Journal of Agrarian Change.

Jayasinghe, Pasan. 2020. Hegemonic Populism: Sinhalese Buddhist Nationalist Populism in Contemporary Sri Lanka. In Populism in Asian Democracies: Features, Structures, and Impacts. Edited by Sook Jong Lee, Chin-en Wu and Kaustuv Kanti Bandyopadhyay. Leiden: Brill.

Jayasuriya, Kanishka. 2018. Authoritarian Statism and the New Right in Asia's Conservative Democracies. Journal of Contemporary Asia 28: 584-604. [CrossRef]

Jha, Dhirendra. 2017. The Fall and Rise of India's Yogi Adityanath. Al Jazeera. Available online: https://www.aljazeera.com/features/ 2017/6/27/the-fall-and-rise-of-indias-yogi-adityanath (accessed on 20 April 2021).

Joshi, Shamani. 2020. 10 Arrested for Interfaith Relationships Under India's "Love Jihad" Law. The Vice. Available online: https:/ / www.vice.com/en/article/jgqga3/10-arrested-for-interfaith-relationships-under-indias-love-jihad-law-uttarpradesh-anti-conversion (accessed on 22 April 2021).

Kapur, Ratna. 2019. "Belief" in the Rule of Law and the Hindu Nation and the Rule of Law. In Majoritarian State: How Hindu Nationalism Is Changing India. Edited by Angana P. Chatterji, Thomas Blom Hansen and Christophe Jaffrelot. Oxford: Oxford University Press.

Katju, Manjari. 2015. The Politics of Ghar Wapsi. Economic and Political Weekly 50: 21-24.

Kovacs, Anja. 2004. You don't understand, we are at war! Refashioning Durga in the service of Hindu nationalism. Contemporary South Asia 13: 373-88. [CrossRef] 
Kuchay, Bilal. 2020. India Police Stop Interfaith Marriage Citing 'Love Jihad’ Law. Al Jazeera. Available online: https:/ /www.aljazeera. com/news/2020/12/4/india-police-stop-interfaith-marriage-citing-love-jihad-law (accessed on 22 April 2021).

Lund, Christian. 2020. Nine-tenths of the Law: Enduring Dispossession in Indonesia. New Haven: Yale University Press.

Mody, Pervez. 2008. The Intimate State: Love-Marriage and the Law in Delhi. London: Routledge.

Moodie, Megan. 2008. Why Can't You Say You Are from Bangladesh?: Demographic Anxiety and Hindu Nationalist Common Sense in the Aftermath of the 2008 Jaipur Bombings. Identities 17: 531-59. [CrossRef]

National Herald. 2021. Entire families of Muslims booked by UP police under 'love jihad' law; women, minor girls not spared. The National Herald. Available online: https:/ / www.nationalheraldindia.com/india/entire-families-of-muslims-booked-by-uppolice-under-love-jihad-law-women-minor-girls-not-spared (accessed on 22 April 2021).

Nielsen, Kenneth Bo, and Alf Gunvald Nilsen. 2021. Hindu Nationalism Statecraft and Modi's Authoritarian Populism. In Routledge Handbook of Autocratization in South Asia. Edited by Sten Widmalm. London: Routledge.

Nilsen, Alf Gunvald. 2020. India's Breaking Point. The Polis Project. Available online: https://thepolisproject.com/indias-breakingpoint/ (accessed on 22 April 2021).

Nilsen, Alf Gunvald. 2015. For a Historical Sociology of State-Society Relations in the Study of Subaltern Politics. In New Subaltern Politics: Reconceptualizing Hegemony and Resistance in Contemporary India. Edited by Alf Gunvald Nilsen and Srila Roy. Delhi: Oxford University Press.

Nilsen, Alf Gunvald. 2019a. Kashmir: Modi's Threat to India's Democracy. Mail and Guardian. Available online: https://mg.co.za/ article/2019-08-07-kashmir-modis-threat-to-indias-democracy/ (accessed on 25 April 2021).

Nilsen, Alf Gunvald. 2019b. The Onward March of Hindu Nationalism. Mail and Guardian. Available online: https://mg.co.za/article/ 2019-11-15-00-the-onward-march-of-hindu-nationalism/ (accessed on 25 April 2021).

Nilsen, Alf Gunvald. 2021. India's Trajectories of Change, 2004-2019. In Destroying Democracy: Neoliberal Capitalism and the Rise of Authoritarian Politics-Democratic Marxism Volume 6. Edited by Vishwas Satgar and Michelle Williams. Johannesburg: Wits University Press.

Noorani, Abdul Ghafoor. 2019. The RSS: A Menace to India. Delhi: Leftword Books.

Pai, Sudha, and Sajjan Kumar. 2018. Everyday Communalism: Riots in Contemporary Uttar Pradesh. New Delhi: Oxford University Press.

Pew Research Centre. 2021. Religious Composition of India. Washington, DC: Pew Research Centre.

Purohit, Kunal. 2019. The Islamophobic Roots of Population Control Efforts in India. Al Jazeera. Available online: https://www. aljazeera.com/features/2019/8/9/the-islamophobic-roots-of-population-control-efforts-in-india (accessed on 25 April 2021).

Rao, Mohan. 2011. On Saffron Demography. Economic and Political Weekly 45: 27-29.

Sahu, Manish. 2021. 1 month of UP 'love jihad' law: 14 cases, 49 in jail, woman 'victim' complainant in only two. Indian Express. Available online: https:/ / indianexpress.com/article/india/love-jihad-law-up-police-7124001/ (accessed on 25 April 2021).

Sarkar, Tanika. 2001. Hindu Wife, Hindu Nation: Gender, Religion and the Prehistory of Indian Nationalism. London: Hurst and Co Publishers.

Sarkar, Tanika. 2002. Semiotics of Terror: Muslim Children and Women in Hindu Rashtra. Economic and Political Weekly 37: $2872-76$.

Sen, Atreyee. 2007. Shiv Sena Women: Violence and Communalism in a Bombay Slum. London: Hurst and Co Publishers.

Sethi, Aman. 2015. "Love jihad" in India and One Man's Quest to Prevent it. The Guardian. Available online: https://www.theguardian. com/world/2015/jan/29/love-jihad-india-one-man-quest-prevent-it (accessed on 28 April 2021).

Sharma, Betwa, and Ahmer Khan. 2021. Hindu Vigilantes Work with Police to Enforce “Love Jihad" Law in North India. The Intercept. Available online: https:/ theintercept.com/2021/07/03/love-jihad-law-india/ (accessed on 28 April 2021).

Srivastava, Prashant. 2020. Yogi Govt Approves "Love Jihad" Ordinance with 3-10 Years of Jail Term, Rs 50,000 Penalty. The Print. Available online: https:// theprint.in/india/yogi-adityanath-govt-approves-love-jihad-ordinance-against-conversionsfor-marriage/551174/ (accessed on 28 April 2021).

Strohl, David James. 2019. Love Jihad in India's Moral Imaginaries: Religion, Kinship, and Citizenship in Late Liberalism. Contemporary South Asia 27: 27-39. [CrossRef]

The Hindu. 2021. U.P.'s Population Control Move Unconstitutional, Say Women's Organisations. The Hindu. Available online: https:/ / www.thehindu.com/news/national/ups-population-control-move-unconstitutional-say-womens-organisations / article35413216.ece (accessed on 30 April 2021).

The Wire. 2020. Haryana Will Bring “Love Jihad" Law “As Soon as Possible": Home Minister. The Wire. Available online: https: // thewire.in/government/haryana-love-jihad-law-as-soon-as-possible-home-minister-anil-vij (accessed on 30 April 2021).

Trivedi, Divya. 2021. Of policy \& prejudice in Uttar Pradesh's population control bill. Frontline. Available online: https: / frontline. thehindu.com/cover-story / of-policy-and-prejudice-in-uttar-pradesh-population-control-bill-2021/article35524180.ece (accessed on 2 May 2021).

Tyagi, Aastha, and Atreyee Sen. 2019. Love-Jihad (Muslim Sexual Seduction) and ched-chad (sexual harassment. Hindu nationalist discourses and the Ideal/deviant urban citizen in India. Gender, Place and Culture 27: 104-25. [CrossRef]

van der Veer, Peter. 2021. Minority Rights and Hindu Nationalism in India. Asian Journal of Law and Society 8: 44-55. [CrossRef]

Varadarajan, Siddharth. 2020. Raising "Love Jihad" Bogey, Yogi Threatens Death for Men Who "Hide Identity, Disrespect Sisters". The Wire. Available online: https:/ / thewire.in/communalism/raising-love-jihad-bogey-yogi-threatens-death-for-men-who-hideidentity-disrespect-sisters (accessed on 2 May 2021). 
Vishwanath, Apurva. 2020. In name of conversion, UP “love jihad” law targets inter-faith unions. Indian Express. Available online: https://indianexpress.com/article/india/up-love-jihad-law-religious-conversion-7075981/ (accessed on 2 May 2021). 